\title{
Comparative midgut ultrastructure in three species of Tardigrada
}

\section{Сравнительное исследование ультраструктуры среднего кишечника у трех видов тихоходок (Tardigrada)}

\author{
Natalia M. Biserova, Alfia R. Mustafina \\ Наталья М. Бисерова, Аһьфия Р. Мустафина
}

Department of Invertebrate Zoology, Faculty of Biology, Moscow State University, Moscow, 119992 Russia. E-mail: nbiserova@yandex.ru; alfia_xx@bk.ru

Кафедра зоологии беспозвоночных биологического факультета МГУ, Москва, 119992 Россия.

KEY WORDS: Eutardigrada, ultrastructure, intestine, enterocytes, glycocalyx, peritrophic membrane, membranous digestion, Halobiotus stenostomus, Richtersius coronifer, Milnesium tardigradum.

КЛЮЧЕВЫЕ СЛОВА: Тихоходки, ультраструктура, средняя кишка, энтероциты, гликокаликс, перитрофическая мембрана, мембранное пищеварение, Halobiotus stenostomus, Richtersius coronifer, Milnesium tardigradum.

ABSTRACT. The ultrastructure and adsorption ability of the midgut in eutardigrades from a variety of marine, freshwater, and terrestrial ecosystems and with either phytophagous or zoophagous feeding habits, as well as having or lacking a capacity for anhydrobiosis have been studied. Differences revealed in the morphology of the intestine, the thickness of the intestinal wall, the nature of the folding of the apical and basal surfaces, intensification of adsorption ability and membranous digestion. It is shown that the maximum values of these attributes are characteristic for Milnesium tardigradum, large predators living in unstable conditions of drip of water bodies, capable to the long anhydrobiosis. These values of phytophagous moss-dwelling Richtersius coronifer are close to those of another phytophagous species Ramazzottius tribulosus. In zoophagous Halobiotus stenostomus (marine species, unable to anhydrobiosis), we identified significant differences in the ultrastructure and morphometric parameters of the intestine between the juvenile and adult stages of the animal. In juveniles (24-h age, did not feed), the digestion membrane surface was increased by 75 times that closely matches the data for other zoophages, Macrobiotus richtersi and Isohypsibius prosostomus. In the intestines of actively feeding adult $H$. stenostomus, we found the powerful development of peritrophic membrane; and morphometric parameters of increasing the membrane surface was significantly reduced (35). In addition, the enterocytes in the front and rear sections of the midgut revealed morphological and functional differences in the ultrastructure. The functional role of the peritrophic membrane in the digestive process is discussed. Our data indicate the existence of ultrastructural adaptations in the intestine of tardigrades with different food preferences and varying ability to rapid response to changes in the environment, in particular the ability to anhydrobiosis.
РЕЗЮМЕ. У 3 видов тихоходок из разных экологических ниш, способных или не способных к высыханию, исследована ультраструктура средней кишки и способность энтероцитов к адсорбции. Выявлены отличия в морфологии кишечника, толщине кишечной стенки, характере складчатости апикальной и базальной поверхности, степени увеличения поверхности для мембранного пищеварения за счет микроворсинок. Показано, что максимальные значения перечисленных признаков характерны для Milnesium tardigradum, крупного хищника, обитающего в нестабильных условиях капельных водоемов, способного к длительному ангидробиозу. Для фитофага, обитающего в пересыхающем мху, Richtersius coronifer, эти значения близко совпадали с другим сходным по местообитанию фитофагом, Ramazzottius tribulosus. У зоофага Halobiotus stenostomus, морской вид, неспособен к высыханию, были выявлены существенные различия в ультраструктуре и морфометрических параметрах кишечника между личиночной и взрослой стадиями животного. У не питавшейся ювенили в возрасте 24 ч, мембранная поверхность увеличена в 75 раз, что близко соответствует данным для других зоофагов Macrobiotus richtersi и Isohypsibius prosostomus. В кишечнике активно питавшегося взрослого H. stenostomus обнаружена мощно развитая перитрофическая мембрана, а морфометрические показатели увеличения мембранной поверхности существенно снижены (35); кроме того, у энтероцитов в переднем и заднем отделах средней кишки выявлены морфофункциональные отличия в ультраструктуре. Роль перитрофической мембраны в процессе пищеварения обсуждается. Полученные данные свидетельствуют о наличии ультраструктурных адаптаций в кишечнике тихоходок с разными пищевыми предпочтениями и различной спо- 
собностью к быстрой реакции на изменение окружающей среды, в частности, способностью к ангидробиозу.

Phyla Tardigrada, Onychophora, and Arthropoda comprise the group Panarthropoda [Nielsen, 2008], which is characterized by the molting of the animal's cuticle, serial pairs of limbs, metamery of the nervous system, and the body cavity, or the hemocoel. According to molecular phylogenetics, these three phyla are related closely [see overview by Reiger et al., 2010].

The nutrition of tardigrades, micro-animals that are found worldwide in a variety of habitats within marine, freshwater, and terrestrial ecosystems, can be phytophagous or zoophagous. The tardigrade's digestive tract consists of three major sections: the foregut, the midgut, and the hindgut. The foregut consists of a buccal tube, two stylets, a myoepthelial pharynx, and an esophagus. Both foregut and hindgut are lined by a cuticle that is shed prior to molting [Dewel et al., 1993; Kinchin, 1994]. The midgut, the largest part of the digestive tract in tardigrades, lacks a cuticular lining, as first evidenced in Isohypsibius augusty [Greven, 1976].

The microscopic anatomy of the tardigrade's digestive system has been partly analyzed in several species of Eutardigrada [Dewel, Clark, 1973a, b, c; Shaw, 1974; Walz, 1975; Greven, 1976; Dewel, Dewel, 1979; Kinchin, 1994; Eibye-Jacobsen, 1996, 1997; Avdonina, Biserova, 2003] and one Heterotardigrada, echiniscidiid [Dewel et al., 1988; Dewel, Eibye-Jacobsen, 2006]. According to Hallas \& Yeates [1972], the width of the buccal tube of the tardigrade correlates to the species' different types of diets. A correlation between the ultrastructure of the digestive system and the diet has not yet been evaluated; the topic has been studied only with respect to Macrobiotus richtersi Murray, 1911 and Ramazzottius tribulosus Bertolani et Rebecchi, 1988 [Avdonina et al., 2007].

The midgut epithelium of Tardigrada, as with other invertebrates, is the first line of defense against environmental changes, pathogens, and excessive levels of, for example, heavy metals and toxic substances. Digestive ability and the potential mechanisms that might be involved in the maintenance of homeostasis and anhydrobiosis have been studied in some species of Tardigrada [Mali et al., 2010; Halberg, Moberg, 2012; Halberg et al., 2013; Rebecchi, 2013].

The aim of our investigation was to compare the ultrastructure and the adsorption ability of the midgut in species from a variety of habitats within marine, freshwater, and terrestrial ecosystems and with both phytophagous and zoophagous diets, as well as with the capacity for anhydrobiosis. Secondarily, we attempted to find differenses between juveniles (24-h age, did not feed) and adults.

\section{Materials and Methods}

Halobiotus stenostomus were collected from filamentous algae in the littoral zone of Eremeevskii ledge near the Kindo Peninsula (Poyakonda, Murmansk Area), at the White Sea Biological Station of Moscow State University. The average size of an adult $H$. stenostomus does not exceed $600 \mu \mathrm{m}$, while that of a juvenile (age $24 \mathrm{~h}$ ) is approximately $100 \mu \mathrm{m}$. Exuviae with eggs cultured in the watch glasses at about $3-5^{\circ} \mathrm{C}$ until hatching and fixed on the next day, after 24 hours*.

For ultrastructural analysis, the animals were fixed in a $2.5 \%$ glutaraldehyde solution in $0.1 \mathrm{M}$ phosphate buffer ( $\mathrm{pH}$ 7.4) with $0.1 \mathrm{M}$ sucrose, washed in the same buffer, postfixed in a $1 \% \mathrm{OsO}_{4}$ solution for $1 \mathrm{~h}$, and embedded in agar. Agar cubes containing the study objects were dehydrated in a graded alcohol series and pure acetone, impregnated with an Araldite-acetone mixture for $48 \mathrm{~h}$, and embedded in Araldite, which was polymerized in two steps, at $37^{\circ} \mathrm{C}$ and $60^{\circ} \mathrm{C}$.

Richtersius coronifer were extracted from mosses collected by V.I. Biserov in 1986, Azerbaijan. After activation in the water ( $48 \mathrm{~h})$, the animals were fixed in a $2.5 \%$ glutaraldehyde solution in $0.05 \mathrm{M} \mathrm{Na}$-cacodilate buffer $(\mathrm{pH} 7.2)$ and postfixed in a $1 \% \mathrm{OsO}_{4}$ solution for $1 \mathrm{~h}$, dehydrated in ethanol and acetone, impregnated with an Araldite-acetone mixture for $48 \mathrm{~h}$, and embedded in Araldite, which was polymerized in two steps, at $37^{\circ} \mathrm{C}$ and $60^{\circ} \mathrm{C}$.

Milnesium tardigradum were extracted from mosses collected on apple trees located in the MSU Botanical Garden, Moscow. Animals were placed in water saturated with $\mathrm{CO}_{2}$ for $5 \mathrm{~min}$ and in a fixed $2.5 \%$ glutaraldehyde solution in $0.05 \mathrm{M} \mathrm{Na}$-cacodilate buffer ( $\mathrm{pH} 7.4$ ) for $22 \mathrm{~h}$, washed in the same buffer, postfixed in a $1 \% \mathrm{OsO}_{4}$ solution in $0.05 \mathrm{M} \mathrm{Na}$-cacodilate buffer $(\mathrm{pH}$ 7.4) for $1 \mathrm{~h}$, dehydrated in ethanol and acetone, and embedded in Epon.

Serial semithin sections $(1.5-2 \mu \mathrm{m})$ were cut on microtome LKB III (Sweden) and stained by method Biserova and Kuznetsova [2012]. The preparations were examined and photographed under a BX51 light microscope (Olympus, Japan). Ultrathin sections were prepared and contrasted, in accordance with method Biserova [2013]. The resulting preparations were examined under JEM-1011 transmission electron microscopes (JEOL, Japan) at the Collective Access Centers for Electron Microscopy of the Papanin Institute of the Biology of Inland Waters, Russian Academy of Sciences, and the Biological Faculty of Moscow State University.

For investigation of the adsorption ability of the digestive epithelium, we used an indirect method to calculate the adsorption ability of the cestode tegument [Biserova and Smetanin, 1982]. By considering a microvillus as a cylinder, we calculated the ratio of a midgut's defined surface area with microvilli to that of a hypothetical equivalent area without microvilli. To calculate the number of microvilli on a 1 square micron slice, the thickness was considered equal to the diameter of the microvillus.

* Cultivation, hatching and fixation of juveniles H. stenostomus have been developed by K.G. Kuznetsova. 


\section{Results}

\section{Midgut ultrastructure of Halobiotus stenostomus, juvenile}

The anterior part of the midgut has a tube-like shape; its central and posterior parts, however, feature deep folds that extend radially folds (Fig. 1).

The midgut epithelium consists of a single layer of cells. The lateral membranes of adjacent cells form extended junctions similar to desmosomes, tight junctions, and gap junctions; the intercellular space between the membranes appears to be electron-dense, and prominent clusters of the electron-dense matrix (dense plate or plate-like densification) were not observed (Figs 2-4). These junctions cover more than one third or one half of the lateral surfaces of epithelial cells (see small arrowheads) and are presented on sections in the form of dark bars surrounding every cell. The cistern of the rough endoplasmic reticulum (Fig. 2) often joins the junction area.

Nuclei, which have an elongated oval shape, are usually located in the basal part of the cells and contain nucleoli. The cytoplasm contains a developed rough reticulum, mitochondria, primary or secondary lysosomes, and vacuoles.

It should be noted that portions of the organelles feature vertical stratification: The nuclei and reticulum are situated in the basal part of the cell and lysosome, and light vacuoles appear in the apical part of the cell. Not all cells of the intestinal epithelium have the same ultrastructure: Some are light cells with a finely-dispersed light cytoplasm and small mitochondria; but cells of this structure lack vacuoles and a developed reticulum (Figs 1, 5).

The apical membrane of the digestive cells in $H$. stenostomus forms typical cylindrical microvilli up to $350 \mathrm{~nm}$ in length and $70 \mathrm{~nm}$ in diameter (Tab. 1).

Microvilli are covered by the glycocalyx consisting in small agglomerates and long filaments (Fig. 3). The apical surfaces of the microvilli contain electron-dense material similar to apical granules.

The peritrophic membrane, visible in the 24-h old hungry animal, presents in the form of vacuoles-like structures and is not available on the entire surface of the epithelium.

The apical surface of the intestine forms deep folds in the central portion of the midgut (Figs 1, 5, and 6). The folds are arranged radially to the longitudinal axis of the body and have a specific structure, as described in the following paragraph.

The fold may be formed by a single cell (type 1) as a deep invagination of the apical surface with microvilli and extending almost to the nucleus (Fig. 5). In another case (type 2), the apical surfaces of the four cells form a deep fold (Fig. 6). Both types of folds belong only to the digestive apical surface of the intestinal epithelium and do not appear on the basal surface.

The cells of the type- 2 fold contain numerous light vacuoles. Within the fold, microvilli locate very close together; the coated pits and vesicles are visible, which then sink into the cytoplasm and merge with lysosomes. The type-1 folds, or unicellular folds, contain phagosomes in the bottom cytoplasms (Fig. 5).

The basal matrix (lamina densa) covers the basalcell membrane at a thickness of $40 \mathrm{~nm}$, resulting in shallow, regular basal folds. The endoplasmic reticulum is well developed in the basal regions of the epithelium cells; deep invaginations of the basal membrane form the basal labyrinth, which is flanked by large mitochondria and vesicles. Due to these ultrastructural components, this region of enterocytes is a zone in which nutrients are actively transported.

\section{Midgut ultrastructure of Halobiotus stenostomus, adult}

Internal lumen of the intestine is oval on the cross sections, without radial or other folds (Figs 8-11). The thickness of the midgut wall (height of the epithelial cells) ranges from 4 to 6.5 microns depending on the location to the longitudinal axis of the body. Anteriorly, the height of the epithelium is greater than that of the posterior portion of the midgut.

With respect to the composition of the organelles, the ultrastructure of the digestive cells of the anterior portion of the midgut differs from that observed in the posterior portion. The front cells contain numerous round electron-dense vacuoles, the diameters of which vary from 0.7 to 2.5 microns (Figs 8,9 ). Smaller vacuoles of average density are situated near the apical membrane and probably correspond to the primary lysosomes (Fig. 11). Large vacuoles of high electron density appear to be lipoprotein granules, resulting in intracellular digestion. There are often lipid droplets, which have a low electron density and are not surrounded by a membrane. Furthermore, this type of cell contains large multivesicular vacuoles of average density; light-translucent vacuoles are extremely rare. The cells of this type have larger apical surfaces facing the lumen of the intestine. The apical membrane features areas that bear microvilli (Tab. 1) that are arranged in groups and which alternate with flat-surface areas without microvilli.

The ultrastructure of the enterocytes demonstrates changes toward the posterior end: The cytoplasm contains many electron-dense granules of various sizes that form large conglomerates (Fig. 10). Conglomerates are not limited to the membrane and completely fill the cytoplasm in some areas. The microvilli on the surface of the posterior cells are of less height and packing density than the anterior enterocytes.

The peritrophic membrane of adults fills the midgut as concentric profiles. The thickness a multilayered peritrophic membrane can be up to $800 \mathrm{~nm}$. The peritrophic membrane, which is connected to the glycocalyx filaments of the microvilli, is more developed in adult animals than in juveniles. A food bolus, located in the peritrophic membrane, lacks plant ultrastructures (Figs 8-11). 

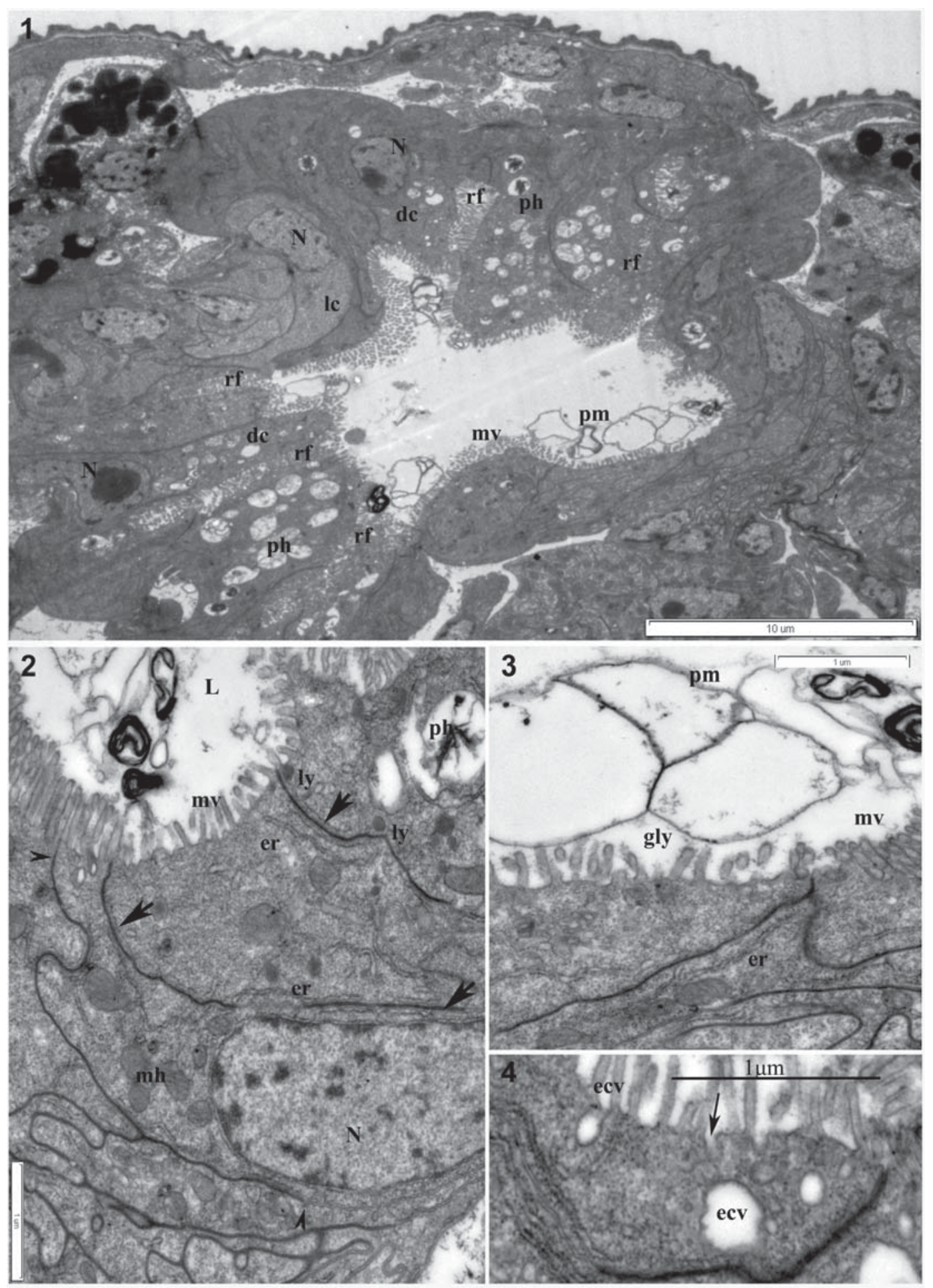

Figs 1-4. Halobiotus stenostomus, juvenile. 1 - cross section of the midgut; it is noted radial folders (rf); microvilli (mv); nuclei (N); peritrophic membrane (pm); digestive epithelial cells (dc) with phagosomes ( $\mathrm{ph})$; lc — light cell; 2 — digestive epithelium with microvilli (mv) and long bands of junctions between cells (small arrowheds) and the cistern of the RER (short arrows); er - endoplasmic reticulum, $\mathrm{L}$ - lumen; ly - lysosome; 3 - peritrophic membrane (pm) and glycocalyx (gly) on the microvillar membrane; 4 - edocytosis (arrow) in the digestive cell; ecv - endocytotic vesicle; other abbreviations see above

Рис. 1-4. Halobiotus stenostomus, ювениль. 1 - поперечный срез кишечника, отмечены радиальные складки кишечника (rf), микроворсинки (mv), ядро (N), перитрофическая мембрана $(\mathrm{pm})$, энтероциты (dc), фагосомы (ph), светлые клетки (lc); 2 энтероциты с микроворсинками (mv) и протяженные ленты контактов между клетками (наконечники) и прилегающие цистерны ШЭР (короткие стрелки); er - эндоплазматический ретикулум; L — просвет кишечника; ly — лизосомы; 3 - пертрофическая мембрана (pm) и гликокаликс (gly) на поверхности микроворсинок; 4 - эндоцитоз (стрелка) в пищеварительной клетке; есv эндоцитозная везикула; остальные обозначения указаны выше. 


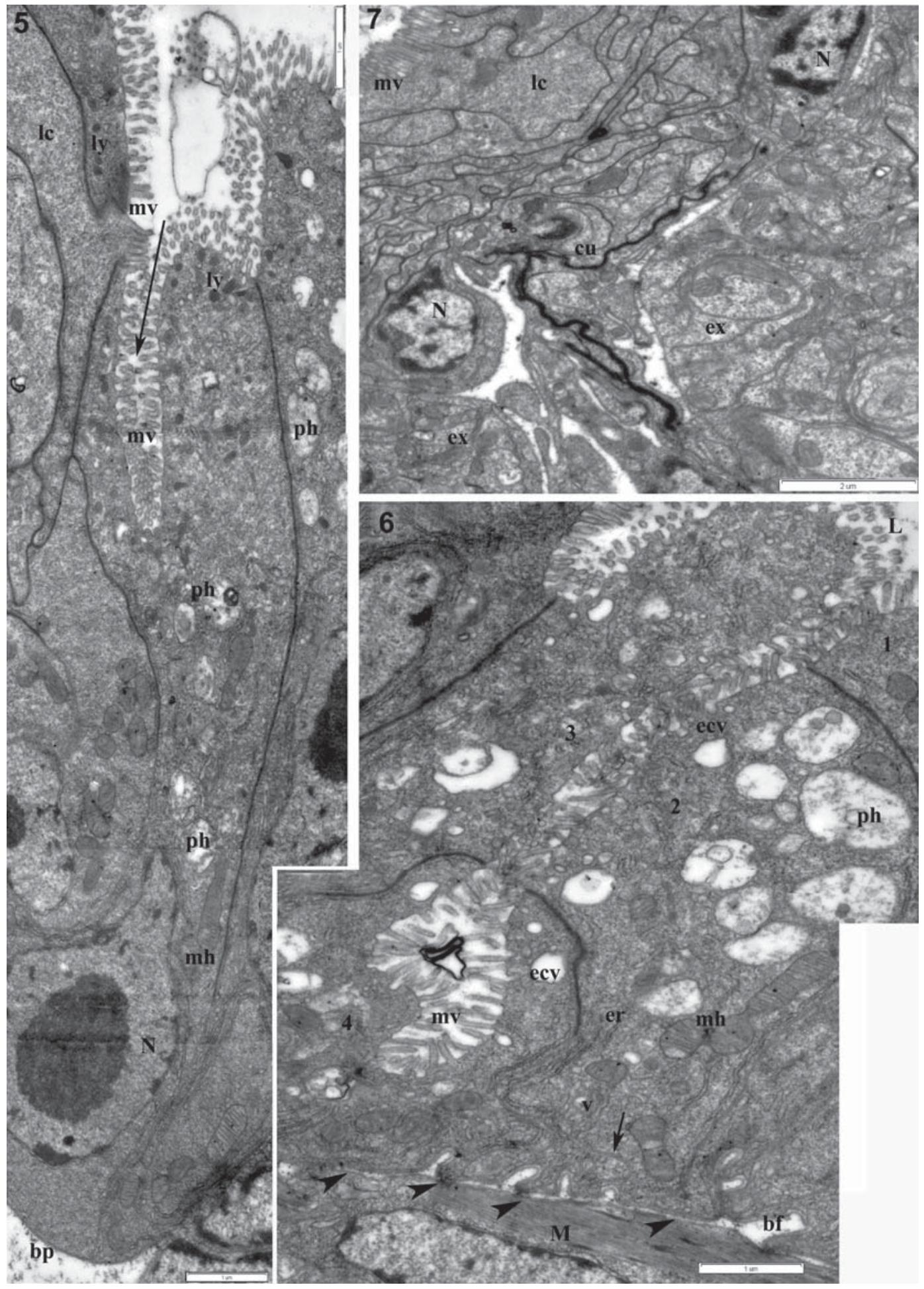

Figs 5-7. Halobiotus stenostomus, juvenile. 5 - one-cell fold of the intestinal wall (arrow); bp - basal plate; other abbreviations see above; 6 - multi-cellar fold of the intestinal wall $(1,2,3,4)$; it is noted the basal labyrinth membrane (arrow), vesicles (v), short folds of the basal plate (bf) and contacts (arrowheads) with the visceral muscles cell (M); other abbreviations see above; 7 - posterior part of the midgut and the beginning of the hindgut; the light cell (lc) lack phagosomes; it is noted microvilli (mv), cuticular layer (cu) and excretory organs (ex).

Рис. 5-7. Halobiotus stenostomus, ювениль. 5 - одноклеточная складка кишечной стенки (стрелка); bp - базальная пластинка; остальные обозначения указаны выше; 6 - многоклеточная складка кишечной стенки (клетки указаны цифрами 1, 2, 3, 4); на фото отмечены мембраны базального лабиринта (стрелка), везикулы (v), короткие складки базальной пластинки (bf) и контакты (наконечники) с висцеральными мышцами (М); остальные обозначения указаны выше; 7 - задняя часть средней кишки и начало задней кишки; светлые клетки (lc) не содержат фагосом; отмечены микровилли (mv), кутикулярный слой (cu) и экскреторный орган (ex). 
Table 1. The characteristics of the microvilli in the tardigrades midgut. Таблица 1. Морфометрические характеристики мембранной поверхности среднего кишечника тардиград.

\begin{tabular}{|l|c|c|c|c|c|c|c|}
\hline & $\begin{array}{c}\text { length } \\
\mathrm{nm}\end{array}$ & $\begin{array}{c}\text { diameter } \\
\mathrm{nm}\end{array}$ & $\begin{array}{c}\text { density } \\
\mathrm{per} \mu \mathrm{m}^{2}\end{array}$ & $\begin{array}{c}\text { the } \\
\text { ratio }\end{array}$ & $\begin{array}{c}\text { peritrophic } \\
\text { membrane }\end{array}$ & $\begin{array}{c}\text { intestine folds } \\
\text { (I, II) }\end{array}$ & diet \\
\hline $\begin{array}{l}\text { Macrobiotus } \\
\text { richtersi }^{3}\end{array}$ & 362 & 45 & 73 & 4.6 & no & + & zoophagous \\
\hline $\begin{array}{l}\text { Isohypsibius } \\
\text { prosostomus }\end{array}$ & 800 & 60 & 141.4 & 22.31 & no & + & zoophagous \\
\hline $\begin{array}{l}\text { Milnesium } \\
\text { tardigradum }\end{array}$ & 850 & 85 & 37.5 & 9.5 & thick, $1 \mu \mathrm{m}$ & - & zoophagous* \\
\hline $\begin{array}{l}\text { Halobiotus } \\
\text { stenostomus, } \\
\text { adult }\end{array}$ & 336 & 72 & 75 & 6.7 & slim & + & phytophagous \\
\hline H.s., juvenile & 750 & 52 & 130 & 17 & slim & + & phytophagous \\
\hline $\begin{array}{l}\text { Richtersius } \\
\text { coronifer }\end{array}$ & 477 & 65 & 111 & 11.5 & yes & + & + \\
\hline $\begin{array}{l}\text { Ramazzottius } \\
\text { tribulosus }\end{array}$ & 85 & & & & & & \\
\hline
\end{tabular}

* according to Prof. A.V. Tchesunov unpublished communication

${ }^{1}$ Avdonina, Biserova, 2003; ${ }^{2}$ Avdonina et al., 2007

\section{Midgut ultrastructure of Milnesium tardigrad- $u m$, adult}

The folded midgut occupies a large part of the body. The midgut wall consists of a thick layer of epithelial cells (up to $20 \mu \mathrm{m}$ in height). A lumen typically looks like a slit. The apical surface of the midgut forms several deep first-order folds, which have second-order folding at the end of deep invaginations (Fig. 12).

Apical microvilli have a cylindrical shape and form a typical brush border (Figs 13-14); in general, they have electron-dense apical caps, or granules. The outer glycocalyx is well developed and both are present on the lateral and apical surfaces of the microvilli. The lengths of microvilli differ significantly on the surfaces of the first- and second-order folds. On the first-order folds, the length of the microvilli ranges from 50 to 60 $\mathrm{nm}$; on the second-order folds, the microvilli length reaches $154 \mathrm{~nm}$ (Figs 13, 23 in rectangle). The ratio between the real surface of a midgut with microvilli and a hypothetic surface without microvilli is 22.3 , and the density per $\mu \mathrm{m}^{2}$ is 141.4 (Tab. 1). Coated pits are regularly visible between microvilli.

Enterocytes exhibit electron-dense cytoplasm, many free ribosomes, and rich rough endoplasmic reticulum, lysosomes, multivesicular bodies, phagosomes and vacuoles. The large nucleus has a central position in the cell and contains a large, dense nucleolus. The lateral surface of the enterocytes possesses contact bands similar to apical complex junctions, which are shorter than those seen in H. stenostomus.

The basal membrane of enterocytes forms deep invaginations of the basal labyrinth (Fig. 15); the adjacent cytoplasm contains lipid droplets and glycogen granules. The basal surface of the midgut exhibits deep folds that contain material of lamina densa and lamina lucida.

\section{Midgut ultrastructure of Richtersius coronifer, adult}

The midgut of $R$. coronifer consists of a single layer of enterocytes which are up to $6-8 \mu \mathrm{m}$ in height. The ultrastucture of the enterocytes in $R$. coronifer was studied for comparative purposes (Figs 16-20). The apical cytoplasm contains many coated vesicles of different sizes and small electron-dense granules. Contrary to $M$. tardigradum, in the enterocytes of $R$. coronifer, the RER is rarely presented, and the lucent cytoplasm contains a few ribosomes. Large phagosomes with geterogenous material have typically been found in the enterocytes.

The microvilli of $R$. coronifer contain electrondense apical granules and are smaller in diameter $(52 \mathrm{~nm})$ than in the other species studied. The glycocalyx is also weakly developed (Fig. 19); it covers every microvillus but does not form the common layer (as in $M$. tardigradum) or long-branched filaments (as in H. stenostomus). The density of microvilli per $\mu \mathrm{m}^{2}$ varies from 110 to 175 , and the ratio between the membrane surface of a midgut with microvilli and a hypothetic surface without microvilli is 17 (Tab. 1).

The peritrophic membrane visible in the lumen (Figs 16, 19) features thin, unilamellar membrane connected to the surface of the microvilli. In the studied animals, the lumen was full of cellular fragments (Fig. 20).

\section{Discussion}

Our investigation of the digestive system in three species of Tardigrada revealed many peculiarities in the midgut ultrastructure. A comparative analysis of several aspects of the midgut ultrastructure was completed in this study. 

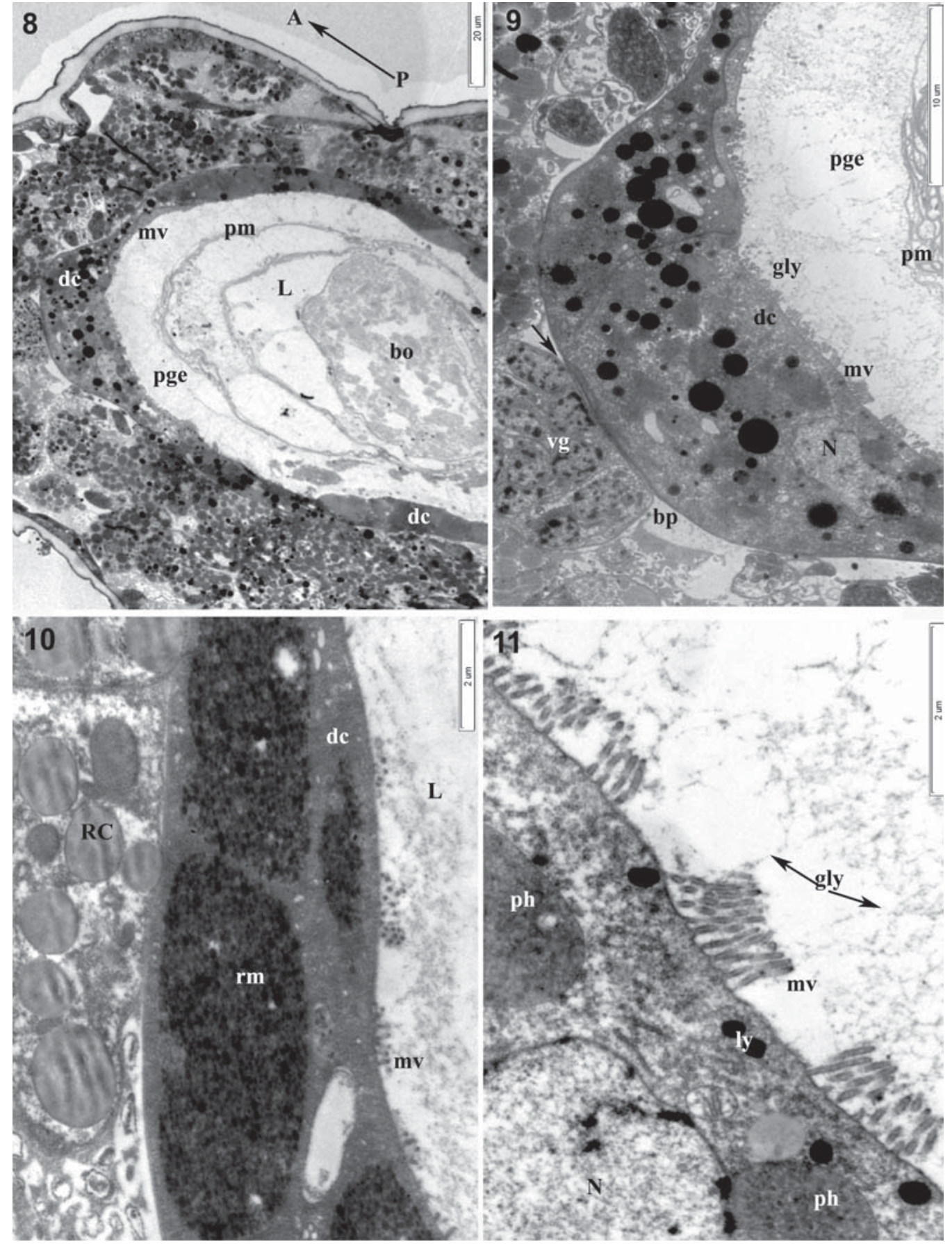

Fig. 8-11. Halobiotus stenostomus, adult. 8 -midgut lumen (L) with peritrophic membrane (pm) and bolus (bo); arrow notes the anterior (A) and posterior (P) end of the body; other abbreviations see above; 9 - digestive cell (dc) with apical microvilli (mv) and the basal plate (bp); the enterocyte's basal surface (lamina dense) adjoins (arrow) to the ventral ganglion (vg); wide layers of the glycocalyx (gly) and peritrophic gel (ge) are presented between microvilli and peritrophic membrane (pm); other abbreviations see above; 10 — the digestive cell (dc) in posterior part of the midgut with small microvilli (mv); it is noted the large granules of the reserve material (rm) and reserve cell (RC); 11 - microvilli and glycocalyx on the anterior portion of the midgut; it is noted large phagosomes (ph), nucleus $(\mathrm{N})$, lysosomes and lipids droplet.

Рис. 8-11. Halobiotus stenostomus, взрослый. 8 - просвет кишечника (L) с перитрофической мембраной (pm) и пищевым комком (bo); стрелкой отмечено направление к переднему (А) и заднему (Р) концу тела; остальные обозначения указаны выше; 9 апикальные микроворсинки (mv) и базальная пластинка (bp) пищеварительной клетки (dc); базальная поверхность энтероцита прилегает (стрелка) к вентральному ганглию (vg). Широкий слой гликокаликса (gly) и перитрофического геля (ge) имеется между микроворсинками и перитрофической мембраной (pm); остальные обозначения указаны выше; 10 - пищеварительные клетки $(\mathrm{dc})$ в задней части средней кишки с мелкими микроворсинками (mv); отмечены крупные гранулы резервного материала (rm) и резервные клетки (RC); 11 - микроворсинки и гликокаликс в передней части средней киши; отмечены крупные фагосомы, ядро, лизосомы и липидные капли. 

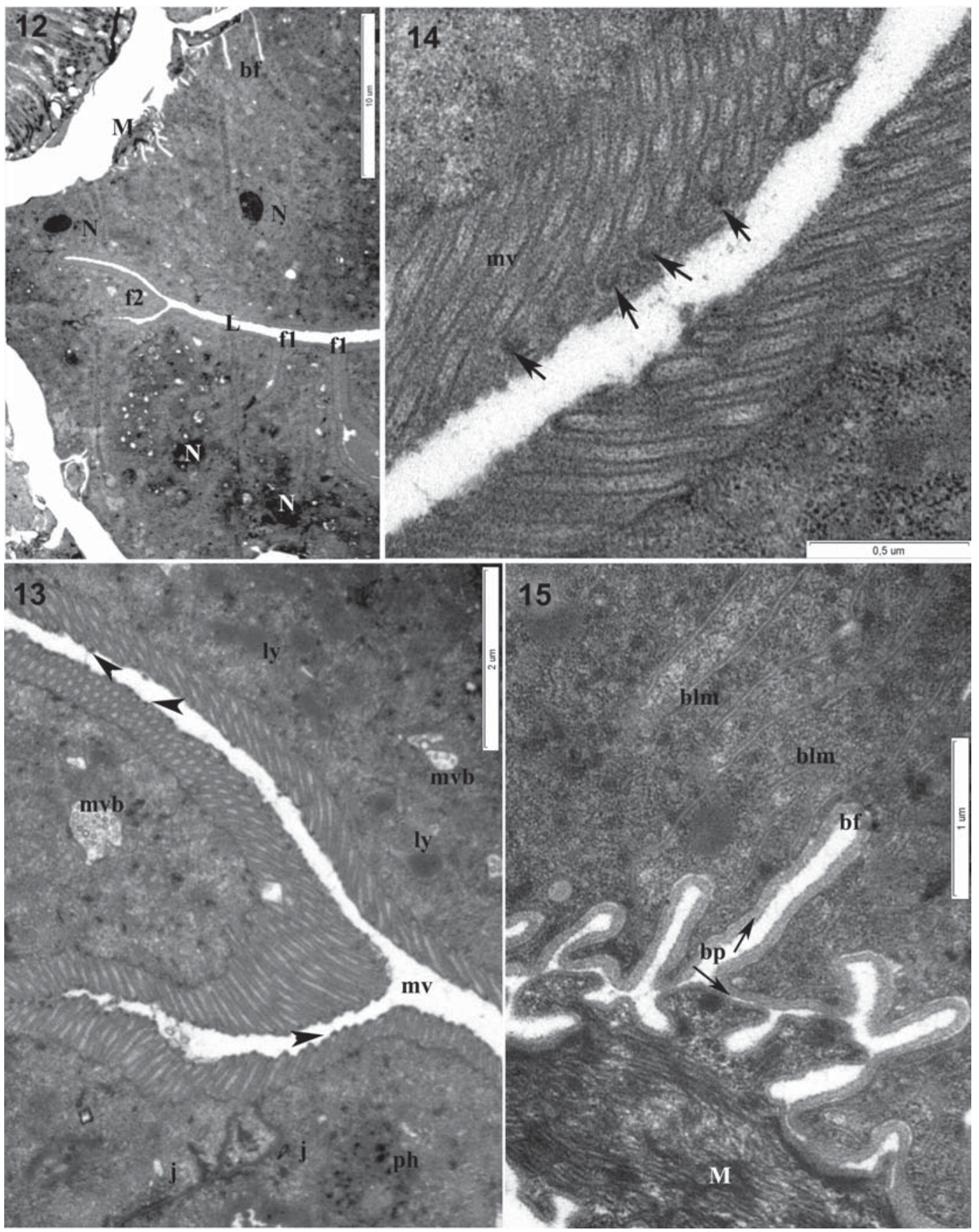

Fig. 12-15. Milnesium tardigradum, adult. 12 - frontal section of the midgut; it is shown apical first- and second-order folds (f1, f2) and basal folds (bf) of the intestine, large enterocytes with nuclei (N) and the visceral muscle (M); L — lumen; 13 -microvilli (mv) on the first-order fold covered by electron dense apical granules (arrows); 14 -microvilli (mv) on the second-order fold; the cytoplasm contains lysosomes (ly), phagosomes (ph), and multivesicular bodies (mvb); $\mathrm{j}$ - junctions; 15 -basal portion of the enterocyte with the basal labyrinth (blm), and basal folds (bf) of the basal plate (bp) covering the midgut (arrows), and the visceral muscle (M).

Рис. 12-15. Milnesium tardigradum, взрослый. 12 - фронтальный срез кишечника; показаны апикальные складки 1-го и 2-го порядка (f1, f2) и базальные складки (bf) кишечника, крупные энтероциты с ядрами (N) и пучки висцеральной мускулатуры $(\mathrm{M}) ; \mathrm{L}$ - щелевидный просвет кишечника; 13 - микроворсинки (mv) в складке 1-го порядка; стрелками отмечены апикальные электронно-плотные гранулы; 14 - микроворсинки (mv) в складке 2-го порядка; цитоплазма содержит лизосомы (ly), фагосомы (ph), и мультивезикулярные тельца (mvb); j - межклеточные контакты; 15 - базальная часть энтероцита с базальным лабиринтом (blm), базальными складками (bf) базальной пластинки (bp) и висцеральными мышцами (M). 

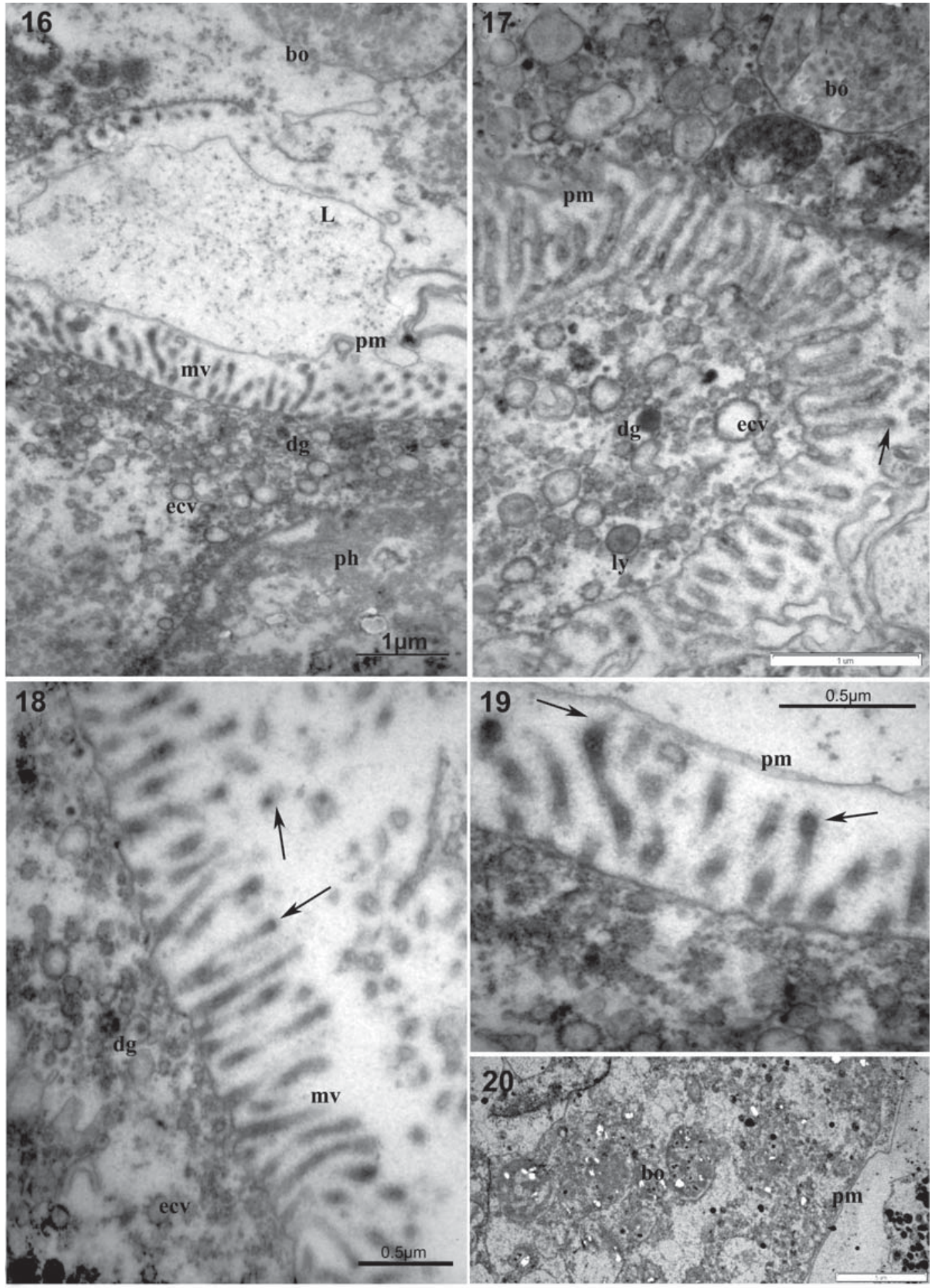

Fig. 16-20. Richtersius coronifer, adult. Ultrastructure of the digestive epithelium: it is noted large phagosome (ph), many endocytotic vesicles (ecv), dense granules (dg) and slim peritrophic membrane ( $\mathrm{pm}$ ); microvilli (mv) covered by tiny glycocalyx (arrows) and the dense apical granule rare have seen (arrows); bo - bolus; L - lumen.

Рис. 16-20. Richtersius coronifer, взрослый. Ультраструктура пищеварительного эпителия: показаны крупные фагосомы (ph), эндоцитозные пузырьки (ecv), плотные гранулы (dg), тонкая перитрофическая мембрана (pm); микроворсинки покрыты тонким гликокаликсом (стрелки), иногда видны электронно-плотные апикальные гранулы (стрелки). bo - пищевой комок; L — просвет кишечника. 


\section{Midgut morphology}

The midgut of the species studied in our research has a tube-like shape without any distinct regions. It is known that in some species (e.g., Dactylobiotus dispar), three distinct regions of the midgut have been distinguished: pro-, meso- and metamesenteron [Ząbczyk, 2000]. The most thick intestinal wall was observed in $M$. tardigradum, and the thinnest wall was seen in H. stenostomus. The nature of the folding of the intestinal wall was different in the studied species of tardigrades (Figs 21-23): First- and second-order folds were found in M. tarigradum (Fig. 23); the secondorder folds were similar to the villi present in the intestines of others animals. In $H$. stenostomus, juvenile, we found unicellular and deep fourth-cellular folds although, in the adult animal, we observed a sac-like midgut which lacks the folds (Figs 21,22). Also we did not find folds in the midgut of $R$. coronifer, first- and second-order folds were present in the midguts of $\mathrm{Mac}$ robiotus richtersi and Ramazzottius tribulosus, as described previously [Avdonina et al., 2007]. In contrast, in Xerobiotus pseudohufelandi (Eutardigrada, Macrobiotidae), the apical cell region forms a large evagination protruding into the midgut lumen, causing the epithelial surface to fold. In these digestive cells, the nucleus is present in this evagination of the apical cytoplasm [Rost-Roszkowska et al., 2013].

\section{Enterocytes}

The enterocytes of the species studied differ in a number of ways. In the posterior portion of the adult $H$. stenostomus midgut, enterocytes reserve a lot of electron-dense nonmembrane-bound material (Fig. 22). These conglomerates were not observed in the enterocytes of $M$. tardigradum or $R$. coronifer. Large spherical electron-dense membrane-bound granules are present in the enterocytes of Echiniscus viridissimus [Dewel et al., 1993]. The authors believe that these structures are released into the midgut lumen as excretory waste. In our investigation, we did not observe excretory activity of the enterocytes. On the other hand, endocytosis was observed in the midgut cells and particularly in juvenile $H$. stenostomus. In the fourth-cellular folds, the apical membrane forms the coated pits and vesicles, which then sink into the cytoplasm.

Glycogen granules and lipid droplets were present in all three species studied. In the midgut epithelium cells of Isohypsibius granulifer granulifer (Eutardigrada), the gradual accumulation of glycogen granules, lipid droplets, and structures of varying electron density were observed [Rost-Roszkowska et al., 2011]. During oogenesis, an increased number of organelles, which are responsible for the intensive synthesis of lipids, proteins, and saccharides, were found. Histochemical analyses of the $X$. pseudohufelandi showed that the enterocytes predominantly contain lipids, whereas proteins and saccharides are rare [Rost-Roszkowska et al., 2013]. The presence of reserve material in the cytoplasm of the digestive cells has also been described in the eutardigrade Dactylobiotus dispar (Murray, 1907) [Ząbczyk, 2000; Rost-Roszkowska, Poprawa, 2008]. Active epithelial transport of organic anions was demonstrated in the tardigrade Halobiotus crispae [Halberg, Moberg, 2012].

\section{Microvillar brush and digestive surface magni- fication}

Midgut cells are connected to one another by junctions that separate the plasma cell membranes into an apical and a basolateral domain. The apical domain is usually modified into finger-like projections, the microvilli, whose shape are ensured by a core of actin that are held in place by various ancillary proteins. In all examined eutardigrades, there was a typical brush border with finger-like microvilli. In contrast, in Echiniscus vurudissimus (Heterotardigrada), the apical surfaces were characterized by irregular lobes with ribosomes and endoplasmatic reticulum [Dewel et al., 1988, 1993].

Our estimation calculated the membrane enlargement of Milnesium tardigradum to be 22.3, that of the Richtersia coronifer to be 17 , and that of the H. stenostomus to be 9.5, which is comparable to that of Isohypsibius prosostomus, which was calculated to be 9 [Avdonina, Biserova, 2003]. This parameter was 11 in Ramazzottius tribulosus and only 4.6 in Macrobiotus richtersi [Avdonina et al., 2007]. It is known that the insect midgut cell microvillus is homologous to that described in vertebrates [Bement, Mooseker, 1996; Terra et al., 2006]. For vertebrates, extension of the gut area by microvilli is an indirect indication of intensification of adsorption ability and membranous digestion [Ugolev, 1967]. We can conclude that species such as Milnesium tardigradum and Richtersia coronifer have high levels of the membranous (contact) digestion and that Macrobiotus richtersi have low levels.

\section{The glycocalyx}

Of the three species studied, the glycocalyx is most developed on the microvilli membrane of $M$. tardigra$d u m$. That fact correlates with the high level of membranous digestion in $M$. tardigradum. It is known that the glycocalyx creates a meshwork and consists of acidic mucopolysaccharides and glycoproteins that project from the apical plasma membrane of epithelial absorptive cells. It provides an additional surface for adsorption and includes enzymes secreted by the absorptive cells that are essential for the final steps in the digestion of proteins and sugars [Ugolev, 1967].

Structure of the glycocalyx in the juvenile and adult midguts of $H$. stenostomus differed: Small particles were present in the juveniles' microvilli (Fig. 3), and long-branched filament meshworks were present in those of the adults (Fig. 8).

\section{Peritrophic membrane}

The peritrophic membrane is an anatomical structure surrounding the food bolus in some arthropods. A 
21 Halobiotus stenostomus, juvenile
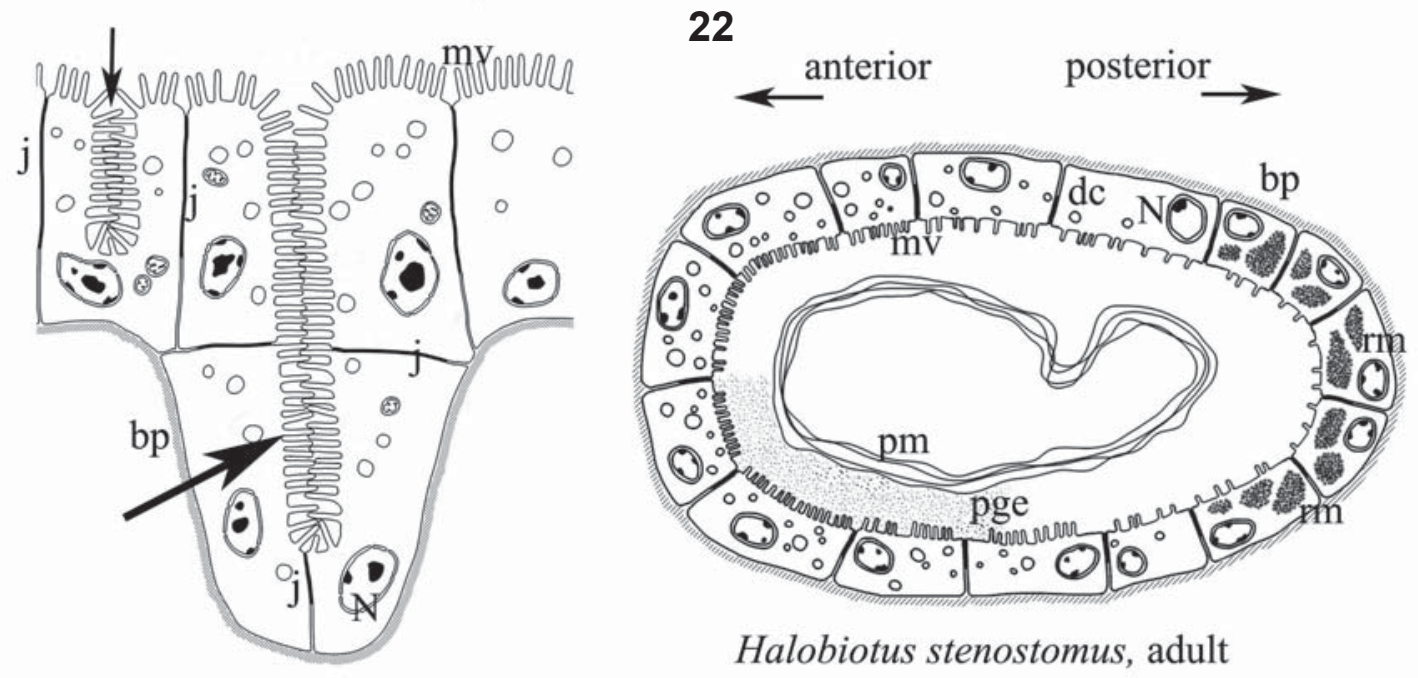

Halobiotus stenostomus, adult

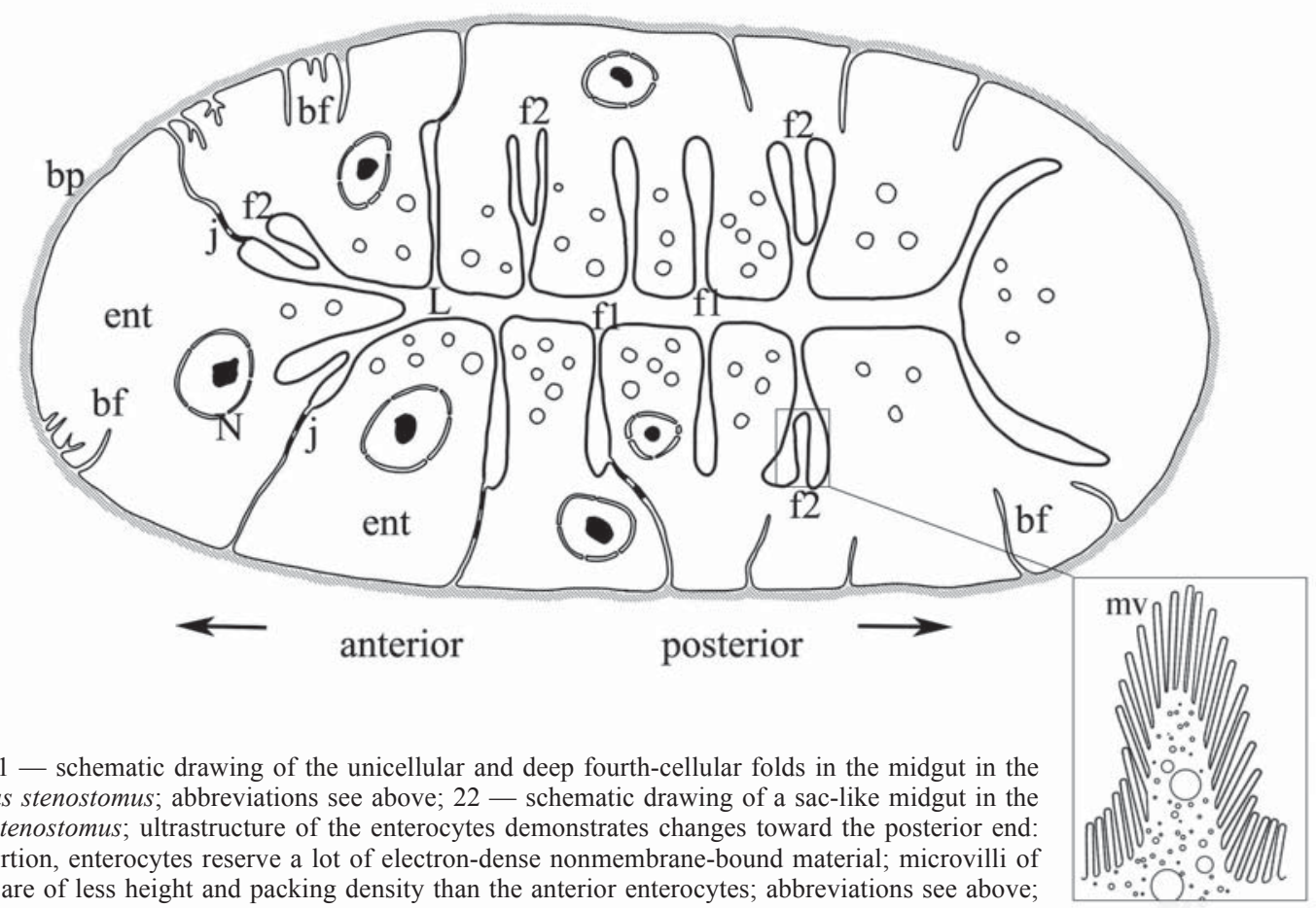

Figs 21-23. 21 - schematic drawing of the unicellular and deep fourth-cellular folds in the midgut in the adult Halobiotus stenostomus; ultrastructure of the enterocytes demonstrates changes toward the posterior end: in the posterior portion, enterocytes reserve a lot of electron-dense nonmembrane-bound material; microvilli of the posterior cells are of less height and packing density than the anterior enterocytes; abbreviations see above; 23 - schematic drawing of the midgut in the Milnesium tardigradum with the apical first- and second-order folds and deep basal folds; in the rectangle it is presented the apical surface of the epithelium with microvili; abbreviations see above.

Рис. 21-23. 21 - схема строения одноклеточной и глубокой 4-клеточной складок в сердней кишке у ювенилього Halobiotus stenostomus; обозначения указаны выше; 22 - схема строения мешковидного кишечника у взрослого Halobiotus stenostomus; ультраструктура энтероцитов изменяется по направлению к заднему концу: в задней части энтероциты накапливают большое количество электронноплотного материала, не ограниченного мембраной; микроворсинки энтероцитов в задней части имеют меньшую высоту и плотность расположения, чем в передней части; обозначения указаны выше; 23 - схема строения средней кишки взрослого Milnesium tardigradum с апикальными складками 1-го и 2-го порядка и глубокими базальными складками; на вставке изображена апикальная поверхность эпителия с микроворсинками; обозначения указаны выше. 
fluid (peritrophic gel) or membranous (peritrophic membrane) film surrounds the food bolus in most insects [Terra, 2001] and acari [Grigorieva, Amosova, 2004], which protects the epithelium against food abrasion and microorganisms; the film has other functions based on the compartmentalization of enzymes. Unfortunately, there are minimum data about the peritrophic membrane in tardigrades. This structure is not noted in microscopical reviews [Dewel et al., 1993; Kinchin, 1994].

We found the peritrophic membrane in the midgut of two species, $H$. stenostomus and $R$. coronifer; and it was more massive in the midgut of adult $H$. stenostomus. In our previous study the peritrophic membrane was found in the midgut of Ramazzottius tribulosus [Avdonina et al., 2007]. We did not observe the peritrophic membrane in the midgut of $M$. tardigradum, which correlates with another previous ultrastructural investigation [Dewel et al., 1988].

In insects, the peritrophic membrane is composed of chitin and proteins, of which peritrophins are the most important [Bolognesi et al., 2001]. It was proposed that during evolution, midgut cells initially synthesized chitin and peritrophins derived from mucins by acquiring chitin-binding domains, thus permitting the formation of the peritrophic membrane [Terra, 2001]. Experimental data have indicated that the peritrophic membrane favors a decrease of enzyme excretion by encouraging enzyme recycling [Terra, 2001]; we suggest that this function occurs in H. stenostomus - a marine species without an anhydrobiosis stage. In contrast, some insects increase the enzyme excretion in the midgut if their peritrophic membrane is disrupted by a diet containing calcofluor [Bolognesi et al., 2001; Terra, 2001]. Compared with $H$. stenostomus, the $M$. tardigradum, hunter-zoophagous, has a desiccation stage; their enterocytes have a richly developed basal labyrinth, microvilli, and glycocalyx. In our opinion, these peculiarities indicate fast transportation of the digested substances to the body cavity during short, active life periods. $M$. tardigradum lack the peritrophic membrane in the midgut and possible has an enzyme excretion rate that is higher than that in H. stenostomus.

In the folds of the juvenile $H$. stenostomus, the process of endocytosis and phagosomes formation is very intensive (Figs 5, 6, 21, 22). The glycocalyx and peritrophic membrane of adults are more richly developed than those in juveniles. We suggest that juvenile has intracellular digestion at the first time. After the juveniles begin to feed, the glycocalyx and the peritrophic membrane start to develop, and extracellular and membranous digestion dominate.

Our data indicate the existence of ultrastructural adaptations in the intestine of tardigrades with different food preferences and varying ability to rapid response to changes in the environment, in particular the ability to anhydrobiosis.

ACKNOWLEDGMENTS. We are grateful to the Collective Access Centers for Electron Microscopy of the Papanin Institute of the Biology of Inland Waters, Russian Academy of Sciences, and the Biological Faculty of Moscow State University for technical assistance. We thank Ksenia G. Kuznetsova for excellent experiments and support. The study was supported by the Russian Scientific Fund (No. 14-50-00029).

\section{References}

Avdonina A.M., Biserova N.M. 2003. [The morpho-functional characteristics of the foregut and midgut of Isohypsibius prosostomus Thulin, 1928 (Eutardigrada) in connection with the peculiarities of food] // Inland Water Biology. Vol.3. P.45-53 [in Russian].

Avdonina A.M., Biserova N.M., Bertolani R., Rebecchi L. 2007. Ultrastructure of the digestive system of Ramazzottius tribulosus and Macrobiotus richtersi (Eutardigrada) in relation with diet // Journal of Limnology. Vol.66. No.1. P.5-11.

Bement W.M., Mooseker M.S. 1996. The cytoskeleton of the intestinal epithelium: components, assembly, and dynamic rearrangements // Cytoskeleton in Specialized Tissues and in Pathological States. Vol.3. P.359-404.

Biserova N.M. 2013. [Methods for visualization of biological ultra structures. Preparation of biological objects for the electron microscopy and confocal laser scanning microscopy. A practical guide for biologists]. Moscow: KMK Scientific Press. 104 p. [in Russian]

Biserova N.M., Kuznetsova K.G. 2012. Head Sensory Organs of Halobiotus stenostomus (Eutardigrada, Hypsibiidae) // Biology Bulletin. Vol.39. No.7. P.579-589.

Biserova N.M., Smetanin M.M. 1982. [About accuracy of increase body surface determination Acantobothrium dujardini (Cestoda: Tetraphyllidea)] // Valuation of methods error of hydrobiology and ichthyology investigations. Rybinsk. P.156-161 [in Russian].

Bolognesi R., Ribeiro A.F., Terra W.R., Ferreira C. 2001. The peritrophic membrane of Spodoptera frugiperda: secretion of peritrophins and role in immobilization and recycling digestive enzymes // Archives of Insect Biochemistry and Physiology Journal. Vol.47. No.2. P.62-75.

Dewel R.A., Clark W.H., Jr. 1973a. Studies on the tardigrades. I. Fine structure of the anterior foregut of Milnesium tardigradum Doyère // Tissue and Cell. Vol.5. P.133-146.

Dewel R.A., Clark W.H., Jr. 1973b. Studies on the tardigrades. II. Fine structure of the pharynx of Milnesium tardigradum Doyère // Tissue and Cell. Vol.5. P.147-159.

Dewel R.A., Clark W.H., Jr. 1973c. Studies on the tardigrades. III. Fine structure of the esophagus of Milnesium tardigradum Doyère // Tissue and Cell. Vol.5. P.161-169.

Dewel R.A., Dewel W.C. 1979. Studies on the tardigrades. IV. Fine structure of the hindgut of Milnesium tardigradum Doyère // Journal of Morphology. Vol.161. P.79-110.

Dewel R.A., Eibye-Jacobsen J. 2006. The mouth cone and mouth ring of Echiniscus viridissimus Peterfi, 1956 (Heterotardigrada) with comparisons to corresponding structures in other tardigrades // Hydrobiologia. Vol.558. P.41-51.

Dewel R., Nelson D., Dewel W. 1993. Tardigrada // Microscopic anatomy of invertebrates. Vol.12. P.143-183.

Dewel R.A., Roush B.G., Dewel W.C. 1988. Fine structure of the midgut cells of the heterotardigrade Echiniscus viridissimus // American Zoologist. Vol.28. No.4. P.149.

Eibye-Jacobsen J. 1996. On the nature of pharyngeal muscle cells in the tardigrada // Zoological Journal of the Linnean Society. Vol.116. P.123-138.

Eibye-Jacobsen J. 1997. Development, ultrastructure and function of the pharynx of Halobiotus crispae Kristensen, 1982 (Eutardigrada) // Acta Zoologica. Vol.78. P.329-347.

Greven H. 1976. Some ultrastructural observations on the midgut epithelium of Isohypsibius augusti (Murray, 1907) (Eutardigrada) // Cell and Tissue Research. Vol.166. P.339-351.

Grigorieva L.A., Amosova L.I. 2004. Peculiarities of the peritrophic matrix in the midgut of tick females of the genus Ixodes (Acarina: Ixodidae) // Parazitologia. Vol.38. No.1. P.3-11. 
Halberg K.A., Moberg N. 2012. First evidence of epithelial transport in tardigrades: a comparative investigation of organic anion transport // Journal of Experimental Biology. Vol.215. No.3. P.497-507.

Halberg K.A., Jorgensen A., Moberg N. 2013. Desiccation tolerance in the tardigrade Richtersius coronifer relies on muscle mediated structural reorganization // PLoS One. Vol.8. No.12. e85091.

Hallas T.E., Yeates G.W. 1972. Tardigrada of the soil and litter of a Danish beech forest // Pedobiologia. Vol.12. P.287-304.

Kinchin I. 1994. The Biology of Tardigrades. Pîrtland: Pîrtland Press. 186 p.

Mali B., Grohme M.A., Förster F., Dandekar Th., Schnölzer M., Reuter D., Wełnicz W., O Schill R., Frohme M. 2010. Transcriptome survey of the anhydrobiotic tardigrade Milnesium tardigradum in comparison with Hypsibius dujardini and Richtersius coronifer // BMC Genomics. Vol.11. P.168.

Nielsen C. 2008. Tardigrada // Animal Evolution. Interrelationship of the Living phyla. Oxford: Oxford University Press. P.226231.

Rebecchi L. 2013. Dry up and survive: the role of antioxidant defences in anhydrobiotic organisms // Journal of Limnology. Vol.72. No.1. P.62-72.

Reiger J., Shultz J., Zwick A., Hussey A., Ball B., Wetzer R., Martin J., Cunningham C. 2010. Arthropod relationships revealed by phylogenomic analysis of nuclear protein-coding sequences // Nature. Vol.463. P.1079-1083.

Rost-Roszkowska M.M., Poprawa I. 2008. Ultrastructure of the midgut epithelium in Dactylobiotus dispar (Tardigrada: Eutardigrada) during encystation // Zoologica Poloniae. Vol.53. P.19-25
Rost-Roszkowska M.M., Poprawa I., Hyra M., Marek-Swedzioł M., Kaczmarek L. 2013. The fine structure of the midgut epithelium in Xerobiotus pseudohufelandi (Iharos, 1966) (Tardigrada, Eutardigrada, Macrobiotidae) // Journal of Limnology. Vol.72. P.54-61.

Rost-Roszkowska M.M., Poprawa I., Wójtowicz M., Kaczmarek L. 2011. Ultrastructural changes of the midgut epithelium in Isohypsibius granulifer granulifer Thulin, 1928 (Tardigrada: Eutardigrada) during oogenesis // Protoplasma. Vol.248. P.405414.

Shaw K. 1974. The fine structure of muscle cells and their attachments in the tardigrade Macrobiotus hufelandi // Tissue and Cell. Vol.6. P.431-445.

Terra W.R. 2001. The origin and functions of the insect peritrophic membrane and peritrophic gel // Archives of Insect Biochemistry and Physiology Journal. Vol.47. No.2. P.47-61.

Terra W.R., Costa R.H., Ferreira C. 2006. Plasma membranes from insect midgut cells // Anais da Academia Brasileira de Ciências. Vol.78. No.2. P.255-269.

Ugolev A.M. 1967. [The physiology and pathology of the membrane (contact) digestion]. Leningrad: Nauka Publ. 230 p. [in Russian].

Walz B. 1975. Ultrastructure of muscle cells in Macrobiotus hufelandi // Memorie dell'Istituto Italiano di Idrobiologia. Vol.32. P.425-443.

Zabczyk I. 2000. Ultrastructural studies on the midgut of Dactylobiotus dispar (Murray, 1907) (Macrobiotidae, Eutardigrada) // Acta Biologica Cracoviensia Series Zoologia. Vol.42. P.9-16.

Responsible editor K.G. Mikhailov 